JALL (Journal of Applied Linguistics and Literacy), ISSN 2598-8530, September, Vol. 4 No. 2, 2020

\begin{tabular}{|ccc|}
\hline Received & Accepted & Published \\
\hline August 2020 & September 2020 & September 2020 \\
\hline
\end{tabular}

\title{
TEACHERS' STRATEGIES IN TEACHING READING COMPREHENSION
}

\author{
Gendis Nadira Dwiningtiyas \\ Gendisnadira@yahoo.com \\ English Education Study Program, Department of Language and Art \\ University of Bengkulu \\ Dedi Sofyan \\ Dedi.sofyan@unib.ac.id \\ English Education Study Program, Department of Language and ArtUniversity of \\ Bengkulu \\ Hilda Puspita \\ hildapuspita@gmail.com \\ English Education Study Program, Department of Language and Art \\ University of Bengkulu
}

\begin{abstract}
This research aimed to figure out the strategies used by English teachers in teaching reading and how they applied the strategies. This research was designed as descriptive qualitative research. Participants of the research were two English teachers who teach in second grade of the school. Each English teacher had eigh meetings that observed by the researcher. The instruments of the research were strategies checklist and interview. The instruments were used to figure out the strategies used and how the English teachers applied the strategies in teaching reading comprehension. The result of the data were analyzed and broken down into three stages; they were Data Reduction, Data Display, and Drawing Conclusion or Interpretation. The result showed that the teacher one used several strategies in teaching reading comprehension. The strategies were brainstorming, reading aloud, and asking for specific information. While the teacher two used nine strategies. They were encouraging the use of dictionaries, reading aloud, reread for checking comprehension, evaluating comprehension in particular tasks, and asking questions for specific information. Both teachers applied and combined the strategies divided into three stages of teaching reading comprehension. The stages were pre-reading stage, while reading stage, and post reading stage. The strategies applied were very effective in teaching reading comprehension in that school. It was proven by the students' motivation, students' attention, and teachers' ease in teaching and learning process.
\end{abstract}

Keywords: Reading Comprehension and Teachers' Strategies. 


\section{INTRODUCTION}

Teaching strategy is generalized plan for a lesson or a lesson which includes structure, desire learner behavior, in terms of the goals of instruction, and an outline of tactics necessary to implement the strategy, Antoni (2010). Teachers strategies often expect students to develop their reading skill by osmosis (absorption) and without help. In the osmosis approach, it is believed that if a teacher teaching reading comprehension to the target language all day, they will improve their reading comprehension. Moreover, according to Brown (2004), the aim of teaching reading is to make students become effective and efficient readers. In order to get the target, the teacher needs to use strategy of reading comprehension.

There are many strategies that teachers can use when they are teaching reading comprehension. According to Setiyadi (2006), some of the strategies are created and used by using authentic material and approaches, reading aloud in the classroom, comprehension question, check the level of difficulty of the text, use pre reading activities to prepare students for reading. In addition, teachers also may use the other strategies such as developing vocabulary of children, not to continue reading without understanding, grasping the heart of matter, using contextual clues, teach reading strategies, visualizing what is written, provide a variety of reading purpose, identify texts and tasks, and so on.

Adler C.R, (2001) stated that teaching reading comprehension strategies are conscious plans-sets of steps that good readers use to make sense of text. Comprehension strategy instruction helps students become purposeful, active readers who are in control of their own reading comprehension. Adler C.R made seven strategies here appears to have a firm scientific basis for improving text comprehension. They are monitoring comprehension, metacognition, graphic and semantic organizers, answering questions, generating questions, recognizing story structure, and summarizing.

In teaching reading, a teacher may use many different strategies. In order to use any instructional technique effectively, anyone who teaches must understand the principles and assumptions upon which eachspecific technique is based. There is certainly no shortage of descriptions or labels for activities that may be 
classified as pertaining to instruction. Harmer (2007) has said that a strategy is an action that the teacher takes to attain one or more of her teaching-learning goals. The strategy can also be defined as a general direction set for the teaching process.

The teacher should use many strategies in teaching reading such as applyingvarious methods, media and games in order to keep the students interested. Brown (2004) has noted that the fundamental feature of teaching strategies is to make it easier to implement a variety of teaching methods and techniques. The key is to create learning environments that are more interactive to apply technology where applicable into the learning experience, and to use appropriate collaborative learning strategies.

In effective teaching of reading comprehension, teachers lead students in the classroom to become proficient and successful readers. Creative teachers do not use only one specific method and technique, but implement many strategies and skills to accommodate the needs andlearning styles of each student in the classroom. Slavin (2000) has also noted that effective instruction is not a simple matter of one person with more knowledge transmitting knowledge to another. Therefore, successful teachers who teach reading realize that reading can be taught by using a variety of strategies. The teaching must be modified by the teachers depending on the students' needs. According to Allington (2002), he notes that creative teachers manage to get better results regardless of curriculum materials, pedagogical approaches and/or reading programs.

It shows that the teacher has an important role in teaching students. Based on the explanation above, the researcher assumed that the role of teachers is very important to overcome students' problem in learning reading comprehension. The teachers should find out various strategies in order to increase the quality of teaching and learning process. The teachers' strategies in teaching reading comprehension become a problem if not overcome soon. For this assumption, the researcher was interested to do descriptive research entitled "English Teachers' Strategies In Teaching Reading Comprehension (A Study At Second Grade Students Of Junior High School 09 Of Bengkulu City)"to analize English teacher strategies. This research was conducted on the Junior High School number 9 Bengkulu City. This research was only focusing on the English teachers' 
strategies of eighth grade of students in that school. The researcher wanted to know what strategies used by the English teachers and how the English teachers implemented the strategies in teaching reading comprehension.

This study aims to find out the teacher's strategy and how they apply the strategies in teaching reading comprehension at the second grade of junior high school 09 in Bengkulu city. The research questions from this study are what are the strategies of the English teacher in teaching reading comprehension in the second grade of junior high school 09 in Bengkulu city?, and How do English teachers apply the strategies in teaching reading comprehension in the second grade of junior high school 09 in Bengkulu city?.

Some researchers have conducted research that focuses on the teacher's strategy in teaching reading comprehension as follows: Janatun (2013) conducted research under the title "Teacher's Strategy in Teaching Listening comprehension". She concluded that the teachers used various strategies in teaching listening. The strategies used by teachers are categorized as bottom-up, top-down and metacognitive. Second previous reserach was conducted by Ahmad (2013) entitled "A Study on Strategies for Teaching Speaking and Reading Comprehension Skills". He concluded that the teachers applied three types of stages in teaching reading namely pre-reading, temporary reading, and postreading stages.

Moreover, Susilowati (2013) conducted a research entitled "the Teacher Strategy in Managing Large Classes in Teaching English in Class XI of Muhammadiyah 1 Karanganyar High School in the academic year 2012/2013”. She concluded that there were two main points found. First, the teacher's strategy in managing a large class in teaching English. Second, the problems faced by the teachers and the students during implementing the teaching strategies and the solutions for the large class.

According to the research conducted by Setiawan(2014) entitle "A Study On Teacher's Strategies In Teaching Reading Comprehension In Second Grade Of Student's MTS Tarbiyatul Ulum". He pointed out that the teachers in that school used various strategies in teaching reading comprehension. The strategies were not too effective because the teacher cannot combine the strategies well. 
The next previous study was from Pulungan (2015) entitle "Teaching Strategy on English Second Language Students". The result showed that the teachers strategies were very important to be applied in teaching English Second Language Students. Moreover, Harida (2016) under the title "Englsih Second Language Teaching” pointed out that English Second Language Students need an appropriate strategy in teaching reading comprehension. Rully (2017) also stated that the teachers can use more than two strategies in teaching reading comprehension toward English Second Language students. This idea was taken from his research under the title "Strategies in Teaching Reading".

Another previous study was conducted by Muslaini (2017) under the title "Strategies in Teaching Reading Comprehension". The result of the research was about the strategies that the teachers should use in teaching reading comprehension. She said that the more strategies used in teaching reading comprehension, the result would be better. The research conducted by Aidil (2014) entitle “A Descriptive Study on Teaching Reading Comprehension Strategies at Junior High School Students SMPN 3 Sabang. He said that the students would be better studying reading reading comprehension if the teacher used appropriate strategies. The other previous study was conducted by Nurhamidah (2018) entitle "The Analysis of Teaching Strategies in Teaching Reading Comprehension". The research showed that strategies that teachers used were very important. The teacher can combine more various strategies in teaching reading comprehension.

The previous studies showed that the teachers' strategies were very effective in teaching reading comprehension. On the other hand, the use of too many strategies would affect students' performances in learning reading comprehension. This reason was contradicted with the research that the researcher conducted in Junior High School Number 9 Bengkulu City. This research showed that the teachers in applying strategies only use two or three strategies. Combination of some strategies was more appropriate compare to many strategies used by the teachers. The students would be more focus if the teacher used fewer strategies but well applied in teaching reading comprehension. 


\section{METHOD}

The researchers used descriptive qualitative design in this study because this study focused on certain phenomena in the school environment. In this case the phenomenon was the activity of learning to teach English. This research also did not need to provide care to the object of research. Then, the researchers observed and explained the phenomenon as in fact as clearly as possible without manipulation. Therefore, the appropriate design could be used in conducting this research was descriptive research. The design of this study was descriptive qualitative with direct observation. Descriptive method is a method used to check the status of groups of humans, an object, condition, thought, and events that will occur (Sugiyono, 2008).

Moreover, Two teachers were involved. They were chosen purposively. They were teachers who had good quality on teaching strategies in teaching reading comprehension and qualified as a professional teacher.The researcher limited the participant by using purposive sampling. it meant that the selecting of participants based on spesific purpose of the research (Musfiqon, 2012). So that, the participation of this research were some good quality teachers in Junior High School number 09 Bengkulu City. In this case, the researcher only took two teachers who had good quality in teaching reading comprehension especially english teacher in the students of class VIII in junior high school 09 of Bengkulu city and it would be able to help researcher in answering the research question. The teachers were volunteering theirselves to do an observation.

Research instrument was tool or facilitiy were used by researcher to collect the data. The result of research were be better, more accurate, complete and systematic. The instrument could be form of quiestionnaire, observation, interview guided, and test. In this research, the researcher used strategy checklist. A major goal for teachers is to have students become lifelong readers, writers, and learners. To accomplish this goal, students need strategies and practice to achieve ownership of their learning, Katherine (1995). With high-stakes tstrategies facing both teachers and students, the teaching and learning process would be conducted easier. 
The teacher was observed by the researcher using the strategy checklist. In this case, The researcher analyzed all the activity in the claass during the teaching learning process especially for the teachers' strategy in teaching reading comprehension. In this stage, the researcher observed the teachers' strategy how they taught their student about reading comprehension and what the strategies that the teacher used in class during the lesson from opening until closing.In this case, The researcher observed whatever done by the English teacher related to the teacher strategies in teaching reading comprehension in the classroom. It was used to investigate the English teaching and learning process in the classroom. It checklisted English teaching process that was conducted by the English teacher. The strategy checlist was adopted from Sarjan (2017).

\section{FINDINGS AND DISCUSSION}

\section{Findings}

\section{a. Teacher One}

In the very first meeting, the first teacher prepared the teaching materials of reading comprehension. She had one text book that same to the students called LKS as the mian material in teaching reading compehension. So far, the students could follow the instructions from the teacher to do all of the activities. Most of them still being condusive in the classroom in the very begining of the activities. The students were very enthusiastic with teachers command and order. Some of the students were also active asked the teacher about what materials that they would do in the teaching and learning process. Eventhough, there were few students who really quite and much didn't care about the materials to do. Based on the researcher observation, the activities done by the teacher were very impactful to the conductivity of the class and to catch students' attention before they started to learn. Those activities then were followed by applying teaching strategies in the main activity of teaching reading comprehension.

Generally, teacher 1 was applying two main strategies in the teaching reading comprehension in the eighth grade of Junior High School number 9 Bengkulu City. The first strategy was reading aloud. This strategy was aimed to excercise the students pronouncing english text. Second strategy was brainstorming. The strategy was aimed to help studnets more understand about text especially 
descriptive text. From the strategies checklsted that the researchers did of teacher 1, these two strategies were significantly help students in learning reading comprehension.

\section{b. Teacher Two}

At first, the teacher also prepared the teaching materials of reading comprehension. The teachers at Junior High School number 9 Bengkulu City were using text book that same to the students called LKS. The text was used as the mian material in teaching reading compehension. Before she started the meeting, she always asked the students to pray in order to teach them the value $f$ of religious. The second teacher was aldo doing the attendence list checked of the students. She wanted to make sure that all of the students present in the class and ready to join the teaching and learning process.

Teacher 2 was applying three main strategies in the teaching reading comprehension in the eighth grade of Junior High School number 9 Bengkulu City. The first strategy was encouraging to use dictionary. This strategy was aimed to remind the students in using dictionary when they read the text. This strategy was significantly helping students in finding the meaning of the words. The next strategy was reading aloud. This strategy was aimed to excercise the students pronouncing english text. Moreover, the strategy was also aimed to help students more understand about text especially descriptive text. The last strategy was evaluating comprehension in particular task. From the strategies checklsted that the researchers did of teacher 1 , these three strategies were significantly help students in learning reading comprehension.

\section{Discussion}

This research was about the teachers' strategy in teaching reading comprehension at second grade students of Junior High School 09 Bengkulu City. This research used descriptive qualitative research design. In this section, there would be discussed the research finding of this study. All the data were collected from two samples of English teachers of the school.

The data results of strategies checklist proved that the first teacher used only Reading Aloud and Asking for Specific Information as the main strategies in teaching reading comprehension. On the other hand, teacher two used 
Encouraging to Use Dictionary, Reading Aloud, and Evaluating Comprehension in Particular Task.

All strategies used were very effective to help the students in learning reading comprehension. It was proven by the condition of the classroom activities and the students' attention in following the teacher while explaining the materials. The strategies used also gave benefit for the teacher. By having the combination of strategies the teacher tought and manage the students easier.

In addition, the both teachers agreed that she used reading aloud was the most suitable and appropriate strategy to teach the students in learning reading comprehension. She pointed out that the most students difficulties in reading comprehension was read and pronouncing the text. This reason became their guidance to have reading aloud as theirr main strategy in teaching the students of reading comprehension.

Those all strategies applied were combined by the teachers in teaching reading comprehension. The combination of these strategies were more effective rather than only used one strategy. It was also supported by the atmosphere of teaching and learning process and the students' attention in following the teaching process. The students' enthusiasim was also good while the teachers used more various strategies in teaching reading.

From the teachers' point of view, combination of strategies was very effective in order to have a good quality of teaching reading comprehension. They were feeling more comfortable in learning and understanding materials by using various strategies. The findings also related with previous studies about teachers' strategies in teaching subjects. The first research was from Janatum (2013) under the title "Teachers' Strategy in Teaching Reading Comprehension". The findings showed that the teachers had the difficulties to get the students' positive response of teaching and learning process. But then, the combination of various strategies were really helped the teachers in gaining students' positive response and having a good quality of teaching.

Second previous research was from Ahmad (2013) entitle "Study on Teachers' Strategies for Teaching Reading Comprehension Skills". These two researchers showed that the role of theacher was very important and the teachers' 
strategy was very important in teaching and learning process. It was very helpful to the students in mastering subjects in various ways. Importantly, the strategy was significantly important to develop the goals of the teaching. The strategy should be appropriate with the goals that wanted to be achieved.

This research was inline with previous researchs that conducted by Janatum and Ahmad. The students faced difficulties in reading comprehension. Since reading foreign language became their problems, the role of teacher was very important to help students in overcoming their problem. Therefore, this research was conducted to support previous findings. The teachers could find appropriate and effective strategies to solve the students' problem. Moreover the teacher could combine the strategies to create better way in teaching reading comprehension.

\section{CONCLUSION}

In the implementation of the teachers' strategies in teaching reading comprehension, the teachers used some strategies in the pre-reading stage, while reading stage and post-reading stage. The strategies that were used by the teacher could develop the idea which readable. Technically, the strategy was combined by the teachers with the others strategies like games and some jokes. It was meant to make the teachers easier in helping the students to master the subjects. Not only the meaning of the words, but also the contents of the texts with funny way but serious. The combination of strategies was very important to apply in order to help students in learning comprehension.

\section{REFERENCES}

Adler C.R, (2001).Comprehension Strategies. \{Online\}. Available: (http://www.readingrockets.org accessed on July 21, 2019).

Ahmad, K (2013).A Study On Strategies For Teaching Speaking And Reading Comprehension Skills.\{thesis\} Language Education, Postgraduate ProgramGanesha University of Education Singaraja, Indonesia.

Aidil, M. (2014). A Descriptive Study on Teaching Reading Comprehension Strategies at Junior High School Students SMPN 3 Sabang. Unpublished Thesis. Syiah Kuala University, Banda Aceh. Arikunto, Suharsimi. (2013). Prosedur Penelitian. Jakarta: Rineka Cipta. 
Arikunto, (1990).Prosedur Penelitian Suatu Pendekatan Praktik. Jakarta: PT Rineka Cipta.

Ary, Donald, (2010).Introduction to Research in Education. Canada: Thomson Wordswort.

Aswan. (2010).Strategi Belajar Mengajar. Jakarta. Reneka cipta.

Antoni, Nurman. (2010).Exploring EFL teachers' strategies in teaching reading comprehension.Indonesia. Indonesia University of Education.

Barnet, M.A. (1988). Teaching Reading in a Foreign Language. [online] retrieved at: http:// www.erictdigests.org/pre-9211/reading.htm. [October, 20 2019]

Cahyono.(2011). The Teaching Language Skill and English Language Components Malang: State university of Malang Press.

Davey, B. (1983). Think aloud : Modeling the Cognitive Processes of Reading Comprehension. Jurnal of reading, 27(1),44-47.

Day, R. R.(1993)..New Ways in Teaching Reading. Teacher of English Speaker of Other Languages.Inc.

Gasong, (2007).Langkah Langkah Pembelajaran Scaffolding. Jakarta. Indonesia Gay, L.R. (1987).Educational Research: Competency for Analysis Application. Third Edition. Colombus Ohio: Merry Publishing Company.

Hadi, (1987).Membaca Cepat dan Efektif. Bandung: Sinar Baru.

Harmer, Jeremy, (2007). The Practice of English Language Teaching, 3rd Ed, New York:

Muslaini. (2017).“Strategies in Teaching Reading Comprehension”. Universitas Syuah Kuala. Banda Aceh.

Nurhamidah, S. (2018). "The Analysis of Teachers' Strategies in Teaching Reading Comorehension”. Universitas Syiah Kuala. Banda Aceh.

Pearson Education Limited.(2001). Isabella, U. Scaffolding Program Pendidikan Usia Dini. Jurnal penabur,

Janatun, Aat Teachers' Strategy In Teaching listening comprehension (thesis) Indonesia University of Education (Upi) 2013

Harmer, Jaremy. (2008). How to Teach English. England Ocelot Publishing. Oxford. 
Kurniawan, A. N. (2017). "Teaching Strategies Use in Reading Comprehension Class at the Tenth Grade Students of SMK Islam Sudirman 2 Ambarawa" Salatiga. IAIN Salatiga.

Laddo, (2017). The Important Of Reading. [Online]. Available: http://www.squidoo.com/the -importance-of-reading [13 November 2007]

Mahmud, T. (2008). "Teaching Reading Strategies Used by ESL Teachers that Facilitate Teaching and Learning Reading”. Malaysia. University Malaysia Sarawak.

Mcneil, John D. (1992) . Reading Comprehension. los Angeles: university of California,

Pulungan, D. (2015). Teaching Strategy on English Second Language Students. Lambung Mangkurat University. Banjarmain

Setiawan. (2014).“A Study on Teachers' Strategies in Teaching Reading Comprehension in Second Grade of Students' MTS Tarbiyatul Ulum”. Blitar.

Harida. (2016). Englsih Second Language Teaching. IAIN Bandung. Bandung. Rully. (2017). Strategies in Teaching Reading. Universitas Pendidikan Indonesia. Bandung. 